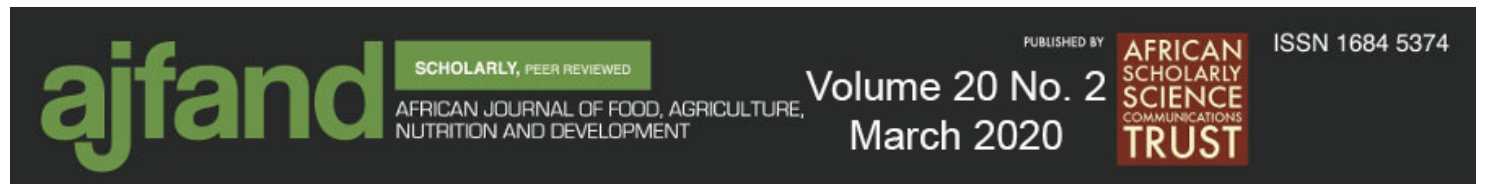

Afr. J. Food Agric. Nutr. Dev. 2020; 20(2): 15474-15489

DOI: 10.18697/ajfand.90.18365

\title{
BANANA AND PLANTAIN IN WEST AFRICA: PRODUCTION AND MARKETING
}

\section{Olumba $\mathrm{CC}^{1}$ and $\mathrm{CN}$ Onunka ${ }^{2 *}$}

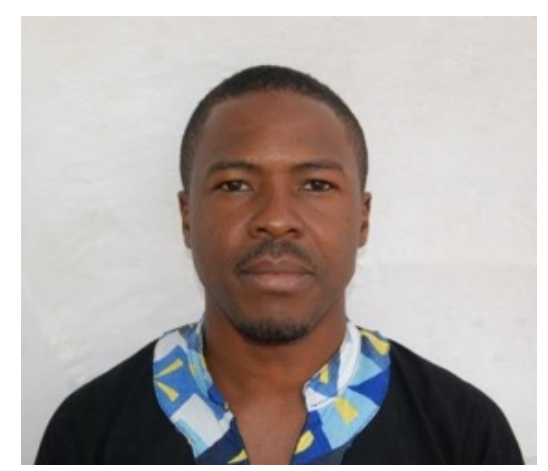

\section{Chukwudi Olumba}

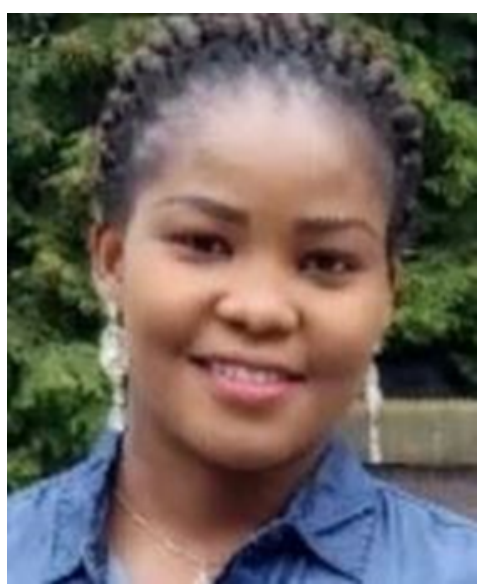

Cynthia Onunka

*Corresponding author email: cynthia.onunka@unn.edu.ng

${ }^{1}$ Department of Agricultural Economics, Management and Extension, Ebonyi State University, Abakaliki, Nigeria

${ }^{2}$ Department of Agricultural Economics, University of Nigeria, Nsukka, Enugu State, Nigeria 


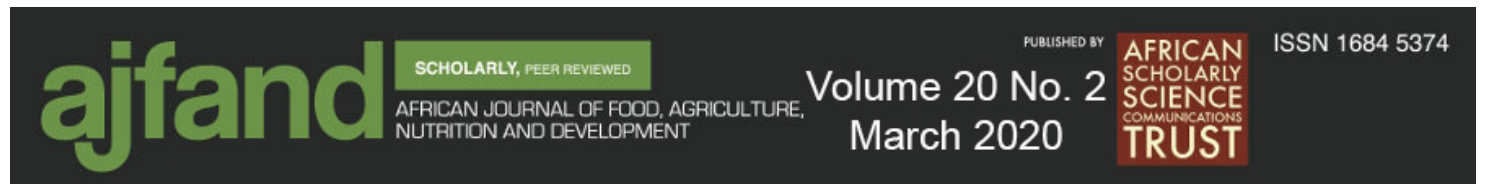

\begin{abstract}
This study provides an overview of banana and plantain in West Africa. West Africa is one of the major plantain-producing regions of the world, accounting for about $32 \%$ of worldwide production. The major plantain-producing countries in the region include Ghana, Nigeria, Côte d'Ivoire, and Guinea. Banana is also cultivated in West Africa but account for only $2.3 \%$ of worldwide production. The major banana-producing countries in the region include Côte d'Ivoire, Guinea, Mali, and Liberia. Banana and plantain have become major food and cash crops in the region. Since the last decade, plantain yields in West Africa have experienced slight increases, with the largest production of 3.7 million metric tons in Ghana, contributing about $13.1 \%$ to the agricultural Gross Domestic Product. Cote d'lvoire ranks the highest producer of bananas with about 320,000 metric tons in West Africa. Although plantain production in West Africa is much higher than banana production, banana is presently of greater importance in terms of world trade. Whereas plantain marketing is characterized by small-scale, widely dispersed producers, banana production is generally more centralized, involving larger production firms and a more structured marketing and transportation system. In West Africa, the sustained production of banana and plantain is endangered by several yield constraining factors including pests and diseases, low technology adoption and environmental factors especially under smallholder management. However, there is room for progress in obtaining bigger yield of these crops. Banana and plantain production enterprises in West Africa have great prospects in the area of employment generation, contributions to national income and gross domestic product, poverty alleviation, economic and industrial growth and rural development. Recommendations are drawn for the provision of market information outfits to disseminate information timely to banana and plantain marketers, price stability, and the need for intensive research on the growth requirements for the sustained production of the crops.
\end{abstract}

Key words: Banana, plantain, Trends, production, Yield, trade, Marketing, Constraints, West Africa 


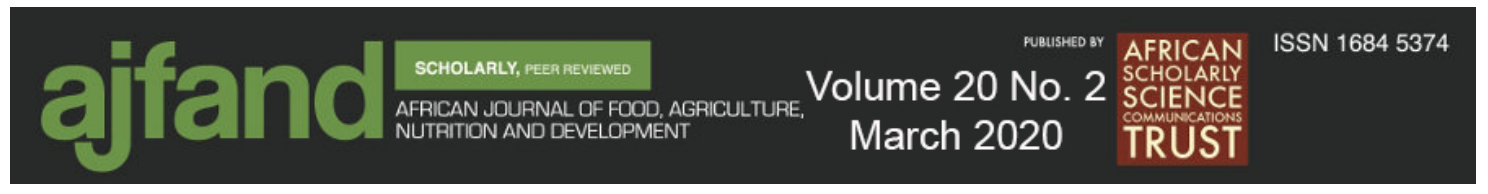

\section{INTRODUCTION}

Banana (Musa sapientum) and plantain (Musa paradisiaca) over the years have occupied considerable positions in agricultural production across the continent representing the world's second largest fruit crop with an annual production of 130 million metric tons [1]. The African continent is among the prominent producers of bananas with Cameroon, Kenya, Cote d'Ivoire, Tanzania and Uganda leading in Africa [2]. Further, there is evidence that Africa leads in the top world producers of plantain with its world production positioning at 33 million metric tons with Cameroon, Nigeria, Rwanda, Ghana, Uganda and Democratic Republic of Congo being the main producing countries [2]. Plantain and banana are in the midst of the most essential staple food crops in the humid forest zones of West Africa [3].

In recent years, the status change of banana and plantain from food to food/cash crop further enhances their importance. Apart from their contributions to food and nutritional security in rural and urban areas [4], these crops have become key sources of revenue as they are not only traded within the region, but also exported to other countries of the world. This notwithstanding, the sustained production of bananas and plantain in the continent, is endangered by several yield constraining factors especially under smallholder management. However, the potential for improving productivity and yield stability of bananas and plantain is thought to be high and would improve food security, increase the agricultural component of the gross domestic product and improve the living standard of the farming population by increasing their incomes.

The study is needed to provide current knowledge aimed at re-awakening the interest of farmers, government as well as other stakeholders in the promotion of the production, trade and marketing of bananas and plantain in West Africa. The study objective is to present key statistics about banana and plantain in West Africa (production, yield, area harvested, and trade since 1991). The study highlights the marketing of plantain and banana, and finally identifies some constraints to the sustained production of the crops in the region.

\section{MATERIALS AND METHODS}

This study concentrates on the major plantain-producing countries of Ghana, Nigeria, Côte d'Ivoire, and Guinea and the major banana-producing countries of Côte d'Ivoire, Guinea, Mali, and Liberia. The data for this study were sourced from the FAOSTAT database [1]. From the FAOSTAT database, a West African plantain and banana database with country-level details were retrieved specially for the study. The choice of these data source is because the FAOSTAT database is an internationally approved, coherent data platform covering key information on inputs, production, costs and socioeconomic indicators, trade and food balances, for a large range of agriculture and forestry products worldwide, which were needed for this study.

Specifically, data were collected on production, yield and trade of banana and plantain covering a twenty five-year from 1971 to 2016. For the production and yield (computed from detailed area and production data) section: the FAOSTAT database had catalogue 


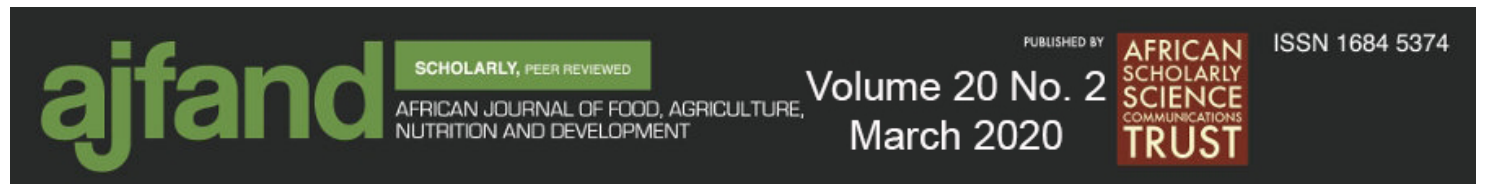

basically for crops grown in field and market gardens mainly for sale, thus excluding crops cultivated in kitchen gardens or small family gardens primarily for household consumption. The unit of measurement for banana and plantain production was measured in metric tons. However, the banana and plantain yields in the FAOSTAT database were presented in hectogram per hectare, hence, we converted the hectogram per hectare to metric tons per hectare which happens to be a more widely standard unit used predominantly by national authorities, peer-reviewed journals and other international organizations.

The trade database includes the following variables: export quantity, export value, import quantity, and import value. The unit of measurement for the export and import values used in the study is US dollars (\$) as against the local currencies to ensure standardization across the sampled countries. While the export and import quantities were in metric tons. Descriptive statistics were used to summarize the data.

Searches for banana and plantain literature were conducted primarily through Google Scholar and the Universities' websites using combinations of the terms such as Africa, West Africa, Nigeria, Ghana, Cameroon, banana, plantain, production, yield, marketing, and trade. Other sources included the Bureau of Statistics and Ministry of Agriculture websites for Nigeria, Ghana, and Cameroon, the International Institute of Tropical Agriculture (IITA), and ProMusa.org.

\section{RESULTS AND DISCUSSION}

\section{Trends in Plantain and Banana Production in West Africa (1991 - 2016) Plantain Production in West Africa}

According to FAOSTAT, the gross value of production of plantain ranks first among food crops in sub-Sahara Africa. Worldwide, seven of the top ten plantain producing countries are in Sub-Saharan Africa, including the West African countries of Ghana, Nigeria, Guinea and Côte d'Ivoire [1]. It is evident from the Figure 1 that Ghana is the largest producer of plantain in West Africa with about 3.95 million metric tons in 2016 contributing about $13.1 \%$ to the agricultural Gross Domestic Product (GDP). On the other hand, Guinea recorded the lowest output of only 469,252 metric tons. 

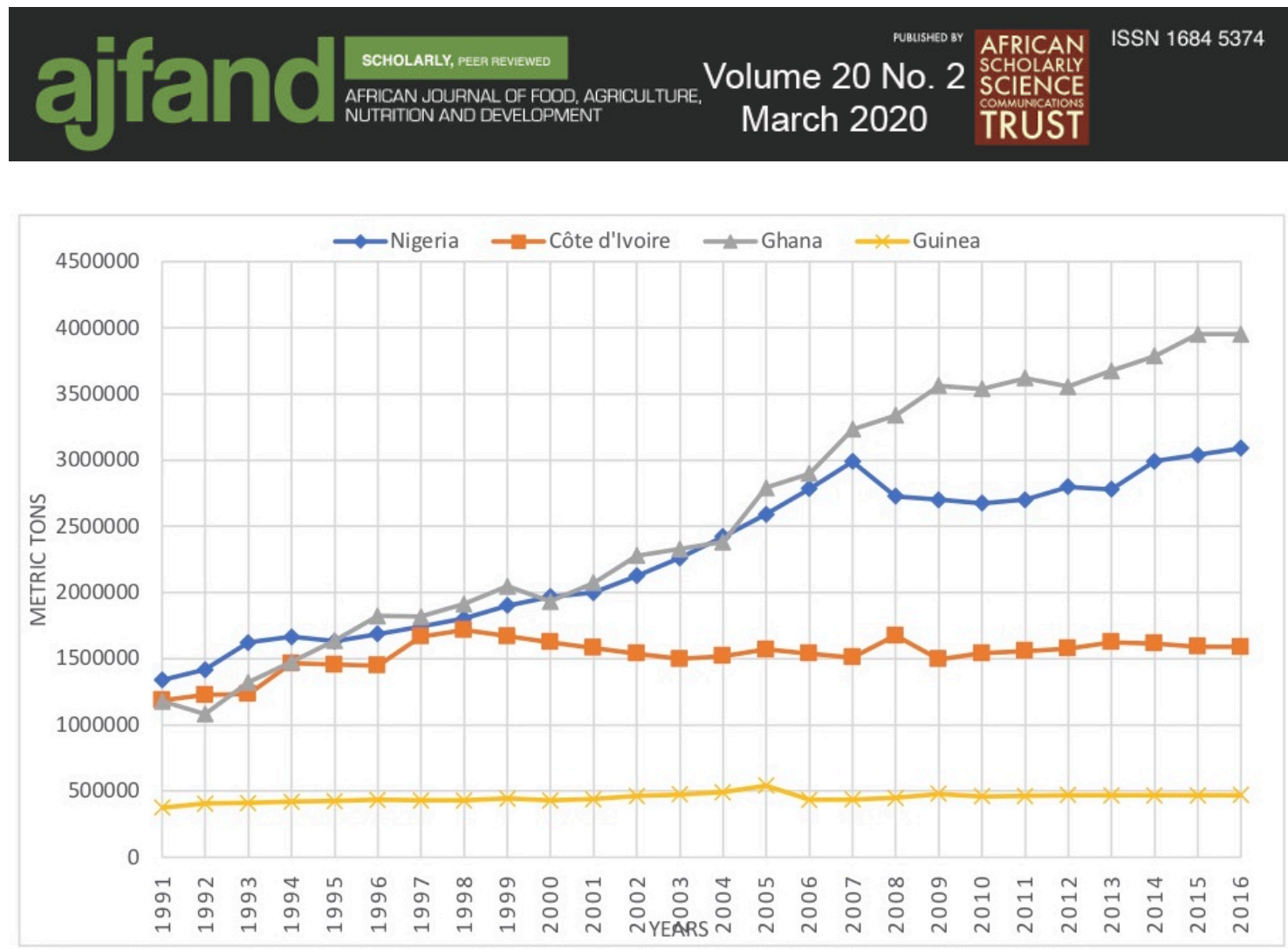

Figure 1: Trend Analysis of Plantain Production in West Africa (1991 - 2016) Source: Authors computation, data retrieved from FAOSTAT 2018

Over the years, plantains from Ghana to the European market have attracted a higher premium than from other producing countries. This is because the geographical location of Ghana places the country in a position to capture the European market compared to other plantain-exporting countries such as Colombia, Ecuador, Venezuela and Costa Rica of the Latin American and Caribbean regions. This geographical advantage held by Ghana might be the reason for her consistency in increased production. Another reason for Ghana's progress in plantain production levels may be due to the expansion of cocoa production, as banana and plantain frequently serve as shade trees for young cocoa plants [5]. Furthermore, observation from Figure 1 shows that Nigeria is the second largest producer with about 2.8 million metric tons, ranking sixth worldwide. However, despite its prominence, Nigeria does not feature among plantain exporting nations because it produces more for local consumption than for export.

\section{Banana production trends in West Africa}

In West Africa, Cote d'lvoire ranks the highest in production of bananas with about 320,000 metric tons followed by Guinea, Mali and Liberia with about 216,000 metric tons, 181,000 metric tons and 132,000 metric tons, respectively. Notwithstanding, only about 1.3 million metric tons of bananas were produced in West Africa, representing $1.5 \%$ of worldwide production in 2013 . 

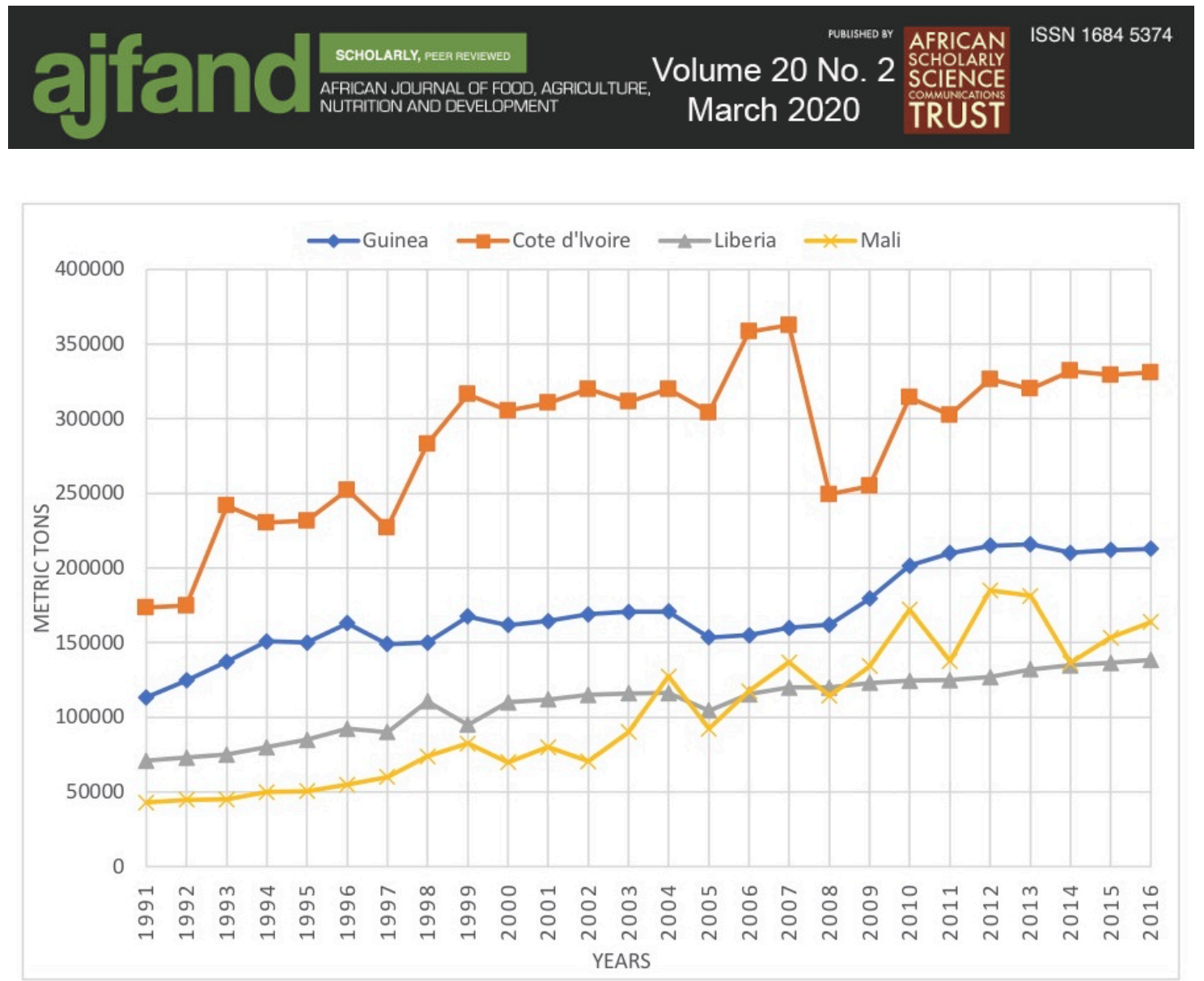

Figure 2: Trend Analysis of Banana Production in West Africa (1991 - 2016) Source: Authors computation, data retrieved from FAOSTAT 2018

Cote d'lvoire, Guinea and Liberia all witnessed declined production in 1991, which is perceived to be connected with the outbreak of the black sigatoka disease. In 2008, Cote d'lvoire's banana production further declined tremendously by 113,453 metric tons. The decline can be explained as a consequence of the heavy rainfall in June 2008 where about 2,500 hectares of banana plantation in Cote d'Ivoire were eroded. However, in the year 2010 Cote d'lvoire's production, bounced back and since then it has steadily been on the increase as shown in Figure 2.

\section{Plantain and Banana Yield in West Africa (1991 - 2016) \\ Plantain Yield in West Africa}

Overall, the yield of plantains in West Africa has increased slightly since 2004, with large increases in Ghana (Figure 3). The high yield in Ghana might be due to the development of five agricultural industries created to meet the increasing demand for plantain [5]. 

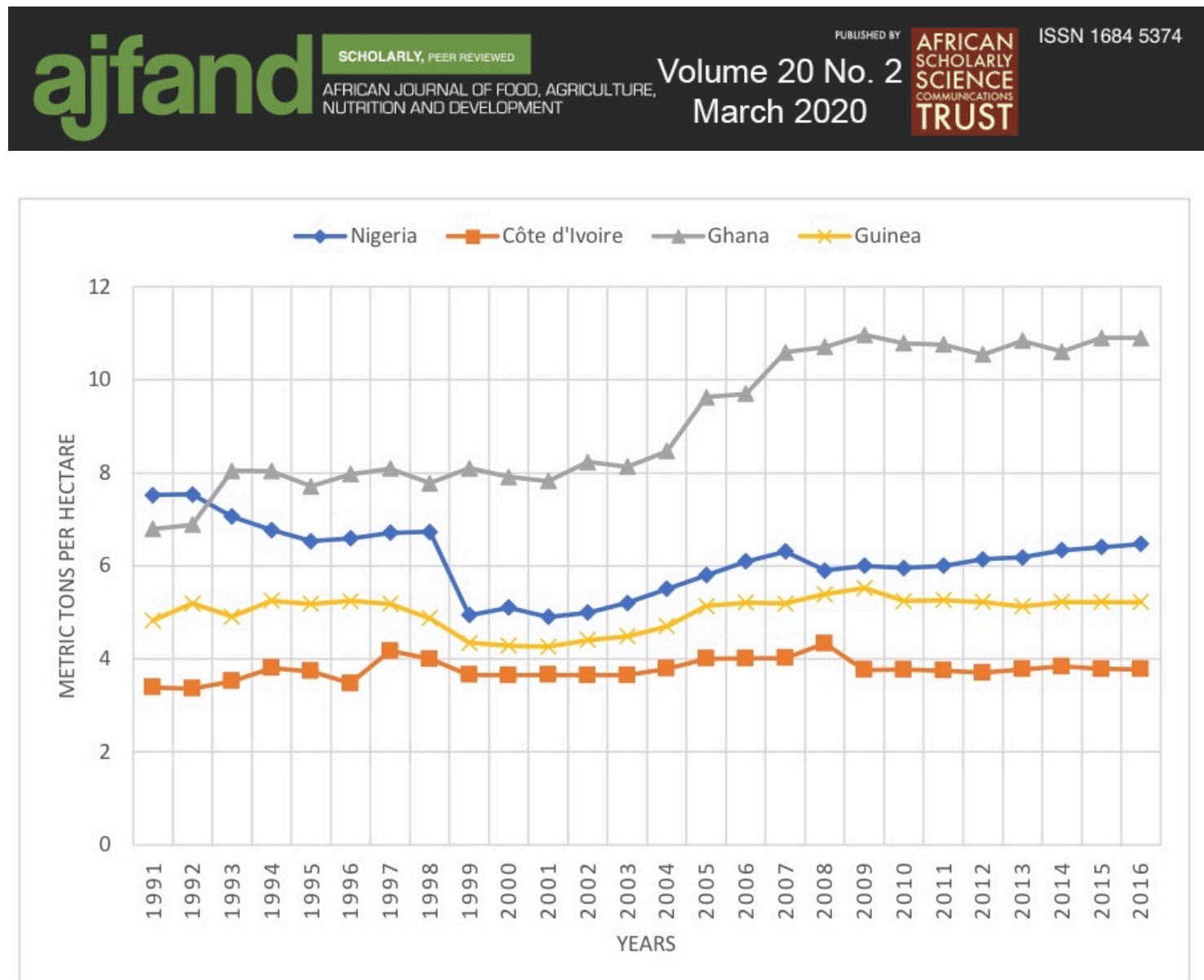

Figure 3: Trend Analysis of Plantain Yield in West Africa, 1991 - 2016 Source: Authors computation, data retrieved from FAOSTAT 2018

Nigeria experienced a great depression in plantain yield from 7.5 metric tons per hectare in 1992 to 4.9 metric tons per hectare in 1999. This may be connected with the outbreak of the black sigatoka, caused by Mycosphaerella fijiensis thus resulting in acute scarcity of the crop and higher cost of the fruits during this period [6]. Yield losses of up to $50 \%$ and more were recorded making the disease a major threat to the farm economy in West Africa [6]. The effort of all stakeholders in combating the disease through release of improved/resistant cultivars might have been responsible for the steady rise in yield in the later years. Yield increased by $28 \%$ from 5.1 metric tons per hectare in 2000 to 6.3 metric tons per hectare in 2007. However, there was a decline in 2008 by $6 \%$ but has since then been slowly increasing.

Guinea and Côte d'Ivoire also experienced depressed plantain yield. In Guinea, yield loss of $19 \%$ was experienced from 5.2 metric tons per hectare in 1996 to 4.3 metric tons per hectare in 2001 while in Côte d'Ivoire, the yield loss was 12\% from 4.2 metric tons per hectare in 1997 to 3.7 metric tons per hectare in 2000. This yield drop, may also be linked to devastating threat of black sigatoka caused by Mycosphaerella fijiensis on plantain production in West Africa [7]. However, in the last decades these countries have experienced fairly stable plantain yield. Overall, the improvement in plantain yields in the last decade could be linked to various research efforts in the region leading to the discovery of hybrid plantain cultivars to replace local verities that are highly susceptible to diseases [8-10]. 


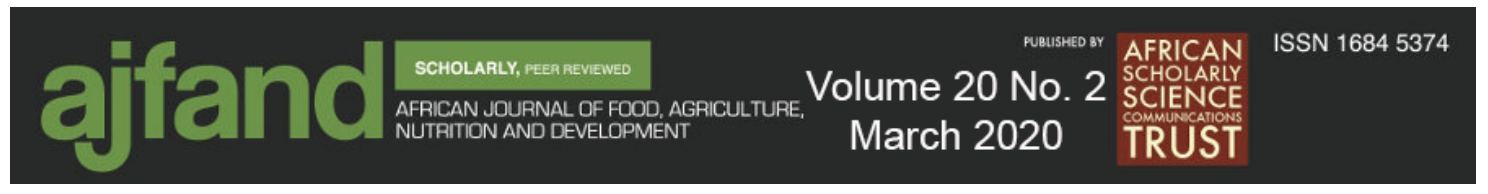

\section{Banana yield in West Africa}

Banana yields vary widely across the countries understudy. While the average yield for bananas in West Africa as a whole was 18.7 metric tons per hectare in 2016, Mali and Côte d'Ivoire both reported significantly higher yields (Figure 4). Neither the available data nor the literature provides an explanation for the high yields in Mali and Côte d'Ivoire as regards to banana production.

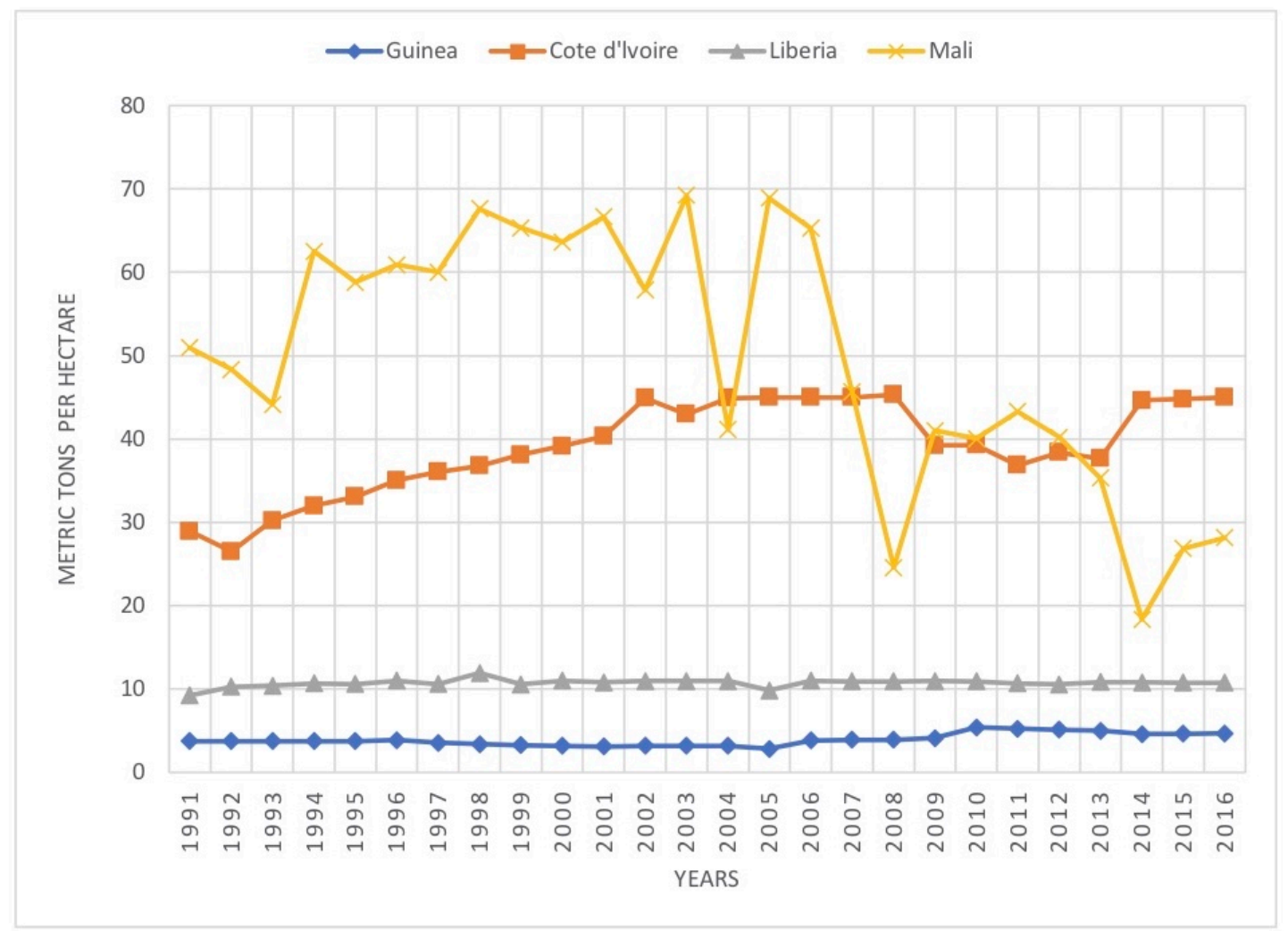

Figure 4: Trend Analysis of Banana Yield for West Africa, 1991 - 2016 Source: Authors computation, data retrieved from FAOSTAT 2018

From Figure 4, it is evident that Mali experienced more drastic drops in Banana yields compared to the other countries under study. According to [11], Bananas in Mali have a high capacity of adaptation under climatic conditions in production areas; hence, producers use the capacity of the plant to vegetatively propagate, to obtain plant material. However, this practice does not guarantee the agronomic quality of plant material, which may partially explain the reduction of yields. This practice is a serious handicap for the development of the banana production in Mali, as it limits the availability of the amount of plant material required for replanting and extensions.

However, it is observed that in 2015, Mali recorded improvement in their production levels. This is because in 2015, the West Africa Productivity Programme (WAAPP) in Mali undertook the promotion of the technology of plant derived from stem fragmentation (PIF) through an operator training. The PIF technology is generated by the National Center of Specialization on plantain based in Côte d'Ivoire and disseminated some of the WAAPP recipient countries including Mali to rebuild the food potential of 


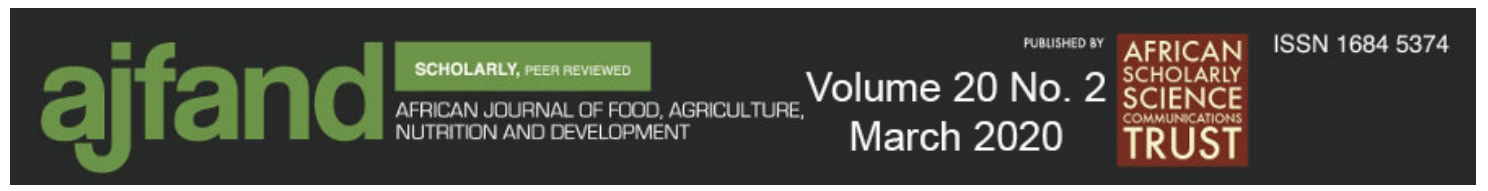

the sub-region. Producers from all the banana production areas (Kayes, Koulikoro and Sikasso), agents of agricultural research and technical support services were trained. The PIF technology is a real alternative to the in vitro culture, which is more expensive and inaccessible to small producers. The production cost of a banana plant by the PIF technique is very low compared to in vitro plants [11].

\section{West African trade in plantain and banana}

In most West African countries, banana production has been consigned to subsistence production. However, a few countries, especially in Francophone West Africa, have recognised the commercial importance of banana, and have used their special relationship with France to export bananas. This has led to the dualization of the banana sector, with the traditional system existing side by side with a modern sector geared towards export trade [12]. However, plantains are only produced in tropical countries and are mostly consumed locally. High technology in the pure culture of plantains is rather uncommon in West Africa. In spite of its increases, production for export represents a very small proportion of the harvest.

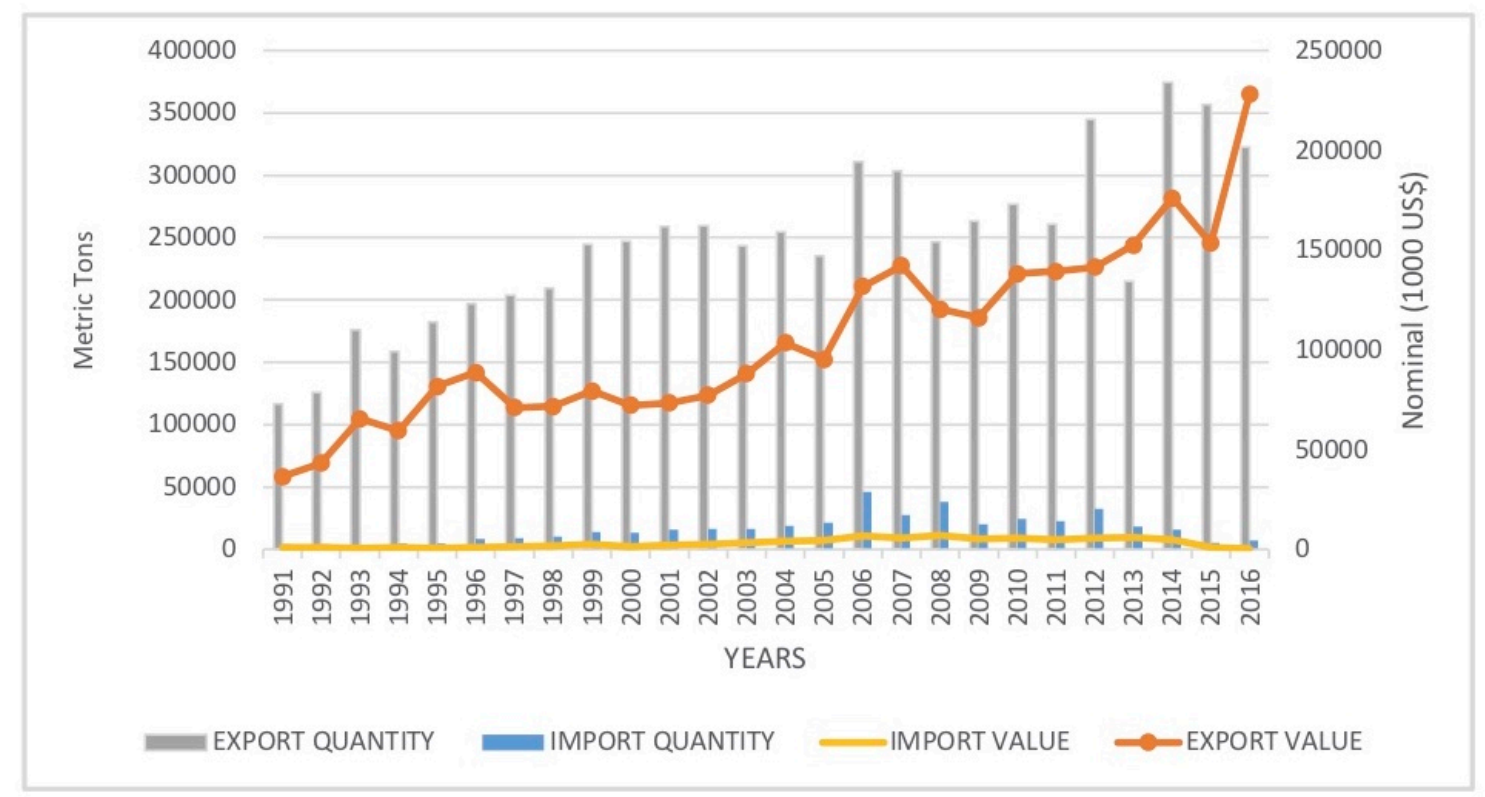

Figure 5: Trend Analysis of Banana import and export in West Africa, 1991 - 2016 Source: Authors computation, data retrieved from FAOSTAT 2018

Although plantain production in West Africa is much higher than banana production, banana is presently of higher importance in terms of world trade, it is a significant source of imports and exports. Plantains are rarely exported but are used locally in various forms [3]. Important changes occurred in the European Union with the liberalization of the market for African, Caribbean and Pacific countries (ACP) of which Cote d'lvoire and Ghana are inclusive, giving them similar advantages to European banana producers. This European Partnership Agreement (EPA), confers additional benefits to ACP countries for as long as the customs tariff for other countries remains high enough. However, the expected severe reduction of this tariff in the near future could make this advantage tenuous $[13,14]$. 
It is obvious from Figure 5 that banana production in the region has grown rapidly over the past decade. Côte d'Ivoire, the largest exporter of banana in the region shipped about 339,357 metric tons of bananas in 2012. Côte d'Ivoire banana exports account for 3.1\% of the global trade, with the majority of these bananas being sold in Europe, mainly in France and the UK. In terms of import, several West African countries import bananas on a small scale. In 2013, the top importers in West Africa were Senegal with 17,066 metric tons and Mali with 1,334 metric tons [1]. It is likely that the import numbers reflect regional trade within West Africa, but the FAOSTAT data did not specify whether that was the case.

\section{Distribution and marketing of banana and plantain in West Africa}

As perishable foodstuffs, bananas and plantains are complex in marketing and distribution. The process involves a large number of producers and a few wholesalers who distribute plantains and bananas to consumers on a large scale. Banana and plantain are mainly marketed fresh and the process depends on the variety and season while few of the processed products such as chips and flour are sold. Numerous players, usually organized in informal networks or chains, may be involved in moving the commodity from the site of production to the ultimate consumer [15]. Women play a key role in the marketing of plantain and banana with the intention of augmenting their family income since it is a profitable venture $[16,17]$. In many cases female market supervisors, often known locally as "market queens," coordinate the marketing activities. They also play a role in regulating the quantity and price, and often, ensure that new entrants are not permitted to sell their produce if they do not belong to that market [5].

In Nigeria, plantain distribution is complex. Farmers whose land lies nearer the major roads harvest the crop at the mature green stage and display it at the roadside or transport it to nearby markets, allowing small-scale wholesalers, retailers and consumers to purchase directly. In other cases, trade collectors move around farms, collect the produce from farmers and transport it to the cities where they hand them over to wholesalers, who in turn pass the produce on to retailers or vendors for sale to customers. Movement and distribution to major cities and other non-producing regions is usually performed by wholesalers [15].

According to a report by the Statistics, Research and Information Directorate, Ministry of Food and Agriculture in Ghana [18], about 299,000 hectares of land is under plantain cultivation producing an annual average of 2.7 million tonnes of fruits, of which more than $95 \%$ are sold on the local market and the rest exported. Like in most other West African countries, Akinyemi et al. [15] further observed that banana and plantain transportation in Nigeria is by road, usually in open or partially closed vehicles. Fruits are packed in bunches and stacked without any form of protection. Small-scale wholesalers and retailers transport fruits by bicycles, wheelbarrows, trucks, pick-ups and taxis. Wholesalers used to transport banana and plantain to more distant markets using trains, lorries and trailers in the 1980s but have been only using lorries and trailers in the last few years. 


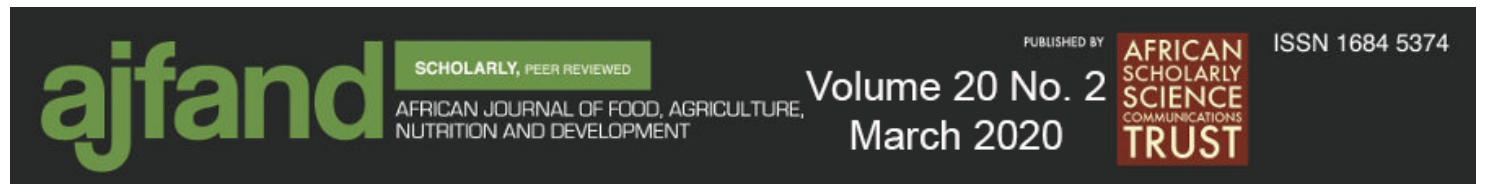

Generally, Adesope et al. [19] opined that generally the postharvest distribution and marketing of banana and plantain in the last 20 years have not been fairly efficient, as there are no established quality and quantity standards for banana and plantain transportation and marketing. A study carried out in Ghana by Dzomeku et al. [5], revealed that marketing of plantain is becoming a cartel in the organized markets. The market queens play a significant role at the organized markets. They determine who should sell on which day and if new entrants come in with produce from the farms, they are prevented from selling. The new entrants are compelled to sell the produce to the middlemen as he or she does not belong to the market structure. A price range is generally set in this type of transaction in order to avoid fluctuations that are too sudden and require produce classification in conformity with the types usually sold. This sometimes causes serious post-harvest losses on the markets [19]. The farmers who bring in their produce from the farms become frustrated by the arrangement. The market responds to the requirements of supply and demand but lacks a regulating body, which has contributed to the development of complex marketing channels. In this context, four main channels leading to the consumer were identified: producer to wholesaler to retailer; producer to retailer; wholesaler to agri-industry; and producer to agri-industry [5].

The plantain and banana business are faced with a lot of marketing problems which determine whether production can be expanded or not [20]. Low farm-gate pricing with traders determining prices has been a major hindrance to production and marketing [21]. Increased production without corresponding well-developed and efficient marketing system may amount to wastage of resources [20]. Thus, agricultural production problems can be overcome through introducing new technology and facilities for storage and processing, and as well as an efficient transportation and marketing systems.

\section{Constraints to plantain and banana production in West Africa}

Agriculture, being a biological production system, faces a host of constraints that have the potential to affect the production system. Across the West Africa continent several constraints related to the production of bananas and plantains have been identified in literature. Disease and pest, environmental factors, low rate of adoption of improved technologies, availability of labour and access to inputs were the most popular factors which constrains bananas and plantains production in the region. This section discusses the various constraints.

Disease and pest: Black leaf streak, burrowing nematodes and banana weevils are the major diseases and pest constraints affecting banana and plantain production in West Africa [22]. Plantain and banana producing areas in the globe have experienced pest and disease pressures which have increased considerably in recent years and a number of important pathogens are causing severe yield losses of 30\% - 50\% [23]. These production risks have been partially mitigated by the introduction of resistant cultivars and better cultural practices [15].

Environmental factors: Plantain and banana shelf-life are affected largely by environmental factors such as wind, humidity and temperature, coupled with lack of ripening techniques and inadequate storage systems. Wind damage is a major problem for banana and plantain producers worldwide. Wind speeds above $40 \mathrm{~km} / \mathrm{hour}$ can 


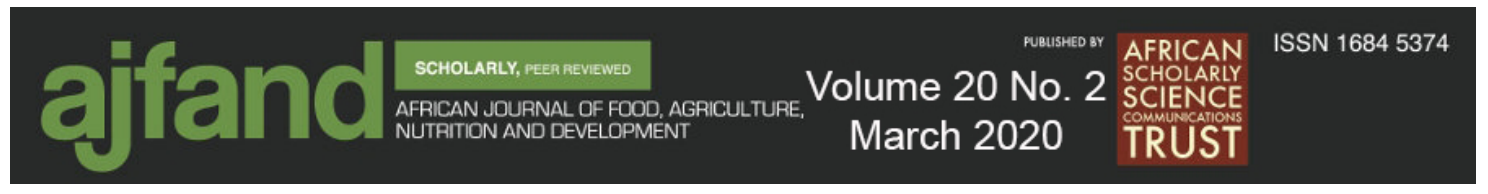

completely destroy a banana plantation [24]. Also, soil analysis carried out in Nigeria's plantain and banana growing regions indicate that the major constraints to plantain and banana production in the soil are the deficiency of phosphorus $(\mathrm{P})$, magnesium $(\mathrm{Mg})$, and potassium $(\mathrm{K})$. The crops require high soil potassium levels for the formation of fruits, and pervasive deficiency of potassium makes the soil unsuitable for plantain production [25].

Low rate of adoption of improved technologies: Studies have shown that the use and promotion of improved plantain technologies result into significant increases in productivity [26]. However, the challenge is that these technologies do not get to the resource-poor farmers and if they do, it is either late or not coinciding with the production period. This may be because of the inefficient extension service delivery systems and competent level of the extension agents in regions [27]. This shortcoming affects the rate of adoption of developed technological packages even when the technologies have immediate obvious and proven advantages.

Availability of labour: Despite lower labour requirements relative to other crops, labour is one of the most significant input constraints on banana and plantain production. This is driven by the high labour costs and shortages due to overlapping planting and harvesting seasons with other crops. In banana-producing countries like Cameroon, modern banana production practices require highly trained personnel, particularly at the managerial level [24]. Shortages of highly trained personnel lead to delays in production and higher post-harvest losses.

Access to inputs: Improving banana and plantain yields requires chemical inputs such as fertilizers, pesticides, and herbicides. In countries such as Cameroon, where the country is a net importer of these goods, production costs are driven even higher by the rising costs of these inputs [24].

Other constraints: In two surveys of plantain and banana production conducted in Nigeria, farmers indicated transportation problems (For example, the lack of good roads, lack of vehicle access, high transportation costs), poor storage conditions, the attitude of farmers toward risk and land tenure arrangement as the major constraints faced in plantain and banana production and marketing [22, 28].

\section{CONCLUSION}

West Africa is one of the major plantain-producing regions of the world, accounting for approximately $32 \%$ of worldwide. Meanwhile, bananas are also grown in West Africa, but they account for only $2.3 \%$ of worldwide. Bananas are more likely than plantains to be grown for export rather than for local consumption. Major constraints to banana and plantain production include pests and disease (such as the black leaf streak virus and nematodes), post-harvest losses, soil degradation, limited knowledge of best practices among smallholder farmers, lack of inputs, and limited labour availability.

Plantain production is dominated by men, but women play a key role in processing and marketing. Whereas plantain marketing is characterized by small-scale, widely dispersed 


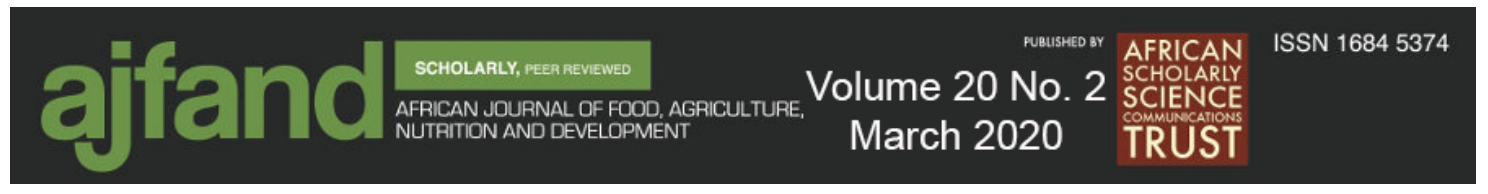

producers, banana production in Cote d'lvoire and elsewhere in West Africa is generally more centralized, involving larger production firms and a more structured marketing and transportation system. Banana and plantain production enterprises in West Africa make significant contribution to local economies in the area of employment generation; contributions to national income and Gross Domestic Product (GDP); poverty alleviation; economic and industrial growth; and rural development. To obtain higher yield of these crops and in a sustainable manner, the following recommendations are proffered.

The effort of farmers should be collaborated with a good and adequate social infrastructure, like better transport systems and efficient extension services. Hence, the need for Government to formulate and implement policies targeted at improving infrastructures and providing market information outfit that disseminates information timely to marketers of banana and plantain. Furthermore, Government should set up or improve their fiscal and monetary policies that stabilize price especially for consumable products like banana and plantain.

In addition, future research on plantains and bananas should address the issue of intensive cropping and nutrient and water requirements to increase productivity both on-station and on-farm with farmers' participation. This will assist in meeting the ever-increasing demand of these crops by both household consumers and the new small-scale industries. Finally, the network among marketers could be improved to limit the influence of middle men (rural assemblers) so as to reduce the final cost of banana and plantain that reaches the ultimate consumer. Given that the higher the number of interventions between producer and consumer, the greater the final price becomes. 


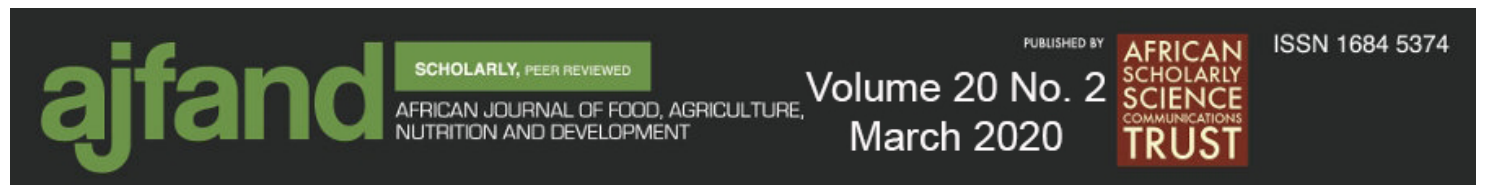

\section{REFERENCES}

1. FAOSTAT. Food and Agriculture Organization of the United Nations Statistics Database. http://www.fao.org/faostat/en/\#data/QC. Accessed 25th June, 2018.

2. FAO. Food and Agriculture Organization of the United Nations. Production Yearbook. FAO Rome. 2006.

3. Faturoti BO, Madukwe MC, Tenkouanoand A and AE Agwu A review of policy acts and initiatives in plantain, and banana system in Nigeria. African $J$ Biotechnology. 2007; 6: 2297-2302.

4. Oladejo JA and WA Sanusi Marketing Analysis of Plantain in Owo and Ose Local Government Areas of Ondo State, Nigeria. Intern J Agric Econ Rural Develop (IJAERD). 2008; 1: 93-101.

5. Dzomeku BM, Dankyi AA and SK Darkey Socioeconomic importance of plantain cultivation in Ghana. J Animal Plant Sci. 2011; 2: 269-273.

6. Jeger MS, Eden-Green JM, Turesh A, Johnson JM and AE Waller Brown Banana Diseases. In: Gowen S. (Eds) Banana and Plantain Commodity Chain in West and Central Africa, Infomusa, 1995: 1.

7. Etebu E and W Young-Harry Control of black Sigatoka disease: Challenges and prospects. Afr J Agric Res. 2011; 6:508-514.

8. Norgrove $\mathbf{L}$ and $\mathbf{S}$ Hauser Improving plantain (Musa spp. AAB) yields on smallholder farms in West and Central Africa. Food security. 2014; 6:501-514.

9. Joseph A, Adesola O, Ademiluyi B and P Ajibola Black Sigatoka severity and growth performance of two plantain cultivars in Omu-Aran, Southern Guinea Savannah of Nigeria. Intern J Biosci (IJB). 2017; 10: 129-134.

10. Tenkouano A, Lamien N, Agogbua J, Amah D, Swennen R, Traoré S, Thiemele D, Aby N, Kobenan K, Gnonhouri G and N Yao Promising highyielding tetraploid plantain-bred hybrids in West Africa. Intern J Agronomy. 2019; $1-8$.

11. West African Agricultural Productivity Program. Adopting banana massive production to rebuild food potential in Mali. 2015. http://www.waappppaao.org/en/success-stories/adopting-banana-massive-production-rebuild-foodpotential-mali. Accessed 30th September, 2019.

12. Fonsah EG, Chidebelu AS and SAND Chidebelu Economics of banana production and marketing in the tropics: A case study of Cameroon. African Books Collective.2011. 


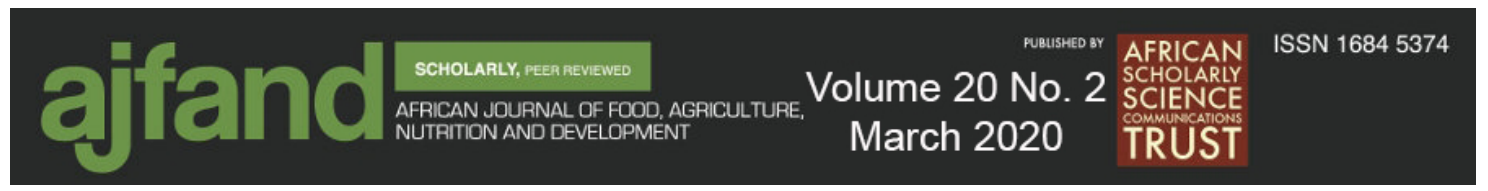

13. Loeillet D Banana market. Banana, ACP and EPA, which way is up? FRuiTRop, 2007a: 7-9.

14. Loeillet D The US legal authorities have decided.... FRuiTRop, 2007b: 1

15. Akinyemi SO, Aiyelaagbe IO and $\mathbf{E}$ Akyeampong Plantain (Musa spp.) cultivation in Nigeria: a review of its production, marketing and research in the last two decades. In T. Dubois, S. Hauser, C. Staver, D. Coyne (Eds.) Proceedings of an international conference on banana \& plantain in africa harnessing international partnerships to increase research impact. Acta Horticulturae. 2010; 879: 211-218.

16. Onyeka UP, Akujuobi GU and UB Anuebunwa Marketing of pantain in Owerri Agricultural Zone of Imo State, Nigeria. J Tech Educ Nigeria. 2004; 9:35 - 39.

17. Fakayode BS, Rahji MAY, Ayinde O and GO Nnom An Economic assessment of plantain production in Rivers State, Nigeria. Intern J Agric Econ Rural Develop. (IJAERD). 2011; 2: 28-36.

18. SRID-MoFA. Statistics, Research and Information Directorate, Ministry of Food and Agriculture, Accra, Ghana. 2006.

19. Adesope AA, Usman JM, Abiola IO and SO Akinyemi Problems and prospects of plantain marketing in Ibadan. Proceedings of 22nd Annual Conference of Horticultural Society of Nigeria. Ibadan, 3rd-6th, September, pp.142 - 145. 2004.

20. Adetunji MO and IO Adesiyan Economic analysis of plantain marketing in Akinyele Local Government Area in Oyo State, Nigeria. Intern J Agric Econ Rural Develop. 2008; 1:15 - 21 .

21. Dankyi AA, Dzomeku BM, Anno-Nyako FO, Adu-Appiah A and G Ntwi Plantain production practices in the Ashanti, Brong-Ahafo and Eastern Regions of Ghana. Asian J Agric Res. 2007; 1:1-9.

22. Bifarin JO and JA Folayan Plantain production in Ondo State, Nigeria: The state of the arts: 2006/2007. Continental J Agric Sci. 2009; 1:27-33.

23. International Institute for Tropical Agriculture (IITA). Plantain and Banana. www.iita.org/banana-andplantian. IITA. 2013.

24. Fonsah EG and AS Chidebelu Economics of banana production and marketing in the tropics: (a Case Study of Cameroon). African Books Collective. 2011.

25. Kumar RA, Kumar $\mathbf{N}$ and M Kavino Role of potassium in fruits crops- A review. Agric Rev. 2006; 27: 284-291.

26. Olumba CC Productivity of improved plantain technologies in Anambra State, Nigeria. Afr J Agr Res. 2014; 9: 2196-2204. 


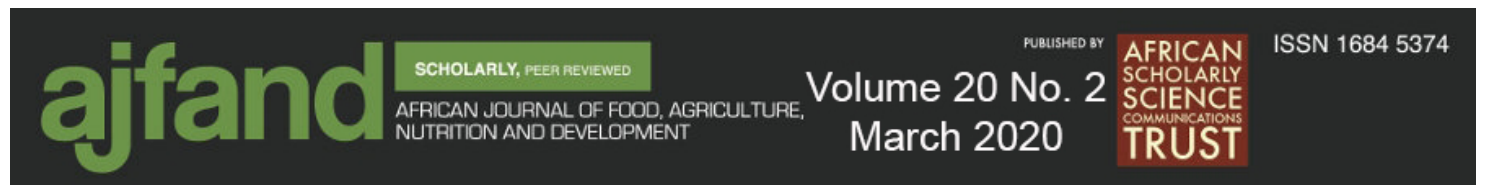

27. Olumba CC and MAY Rahji An analysis of the determinants of the adoption of improved plantain technologies in Anambra State, Nigeria. J Agric Sustainability. 2014; 5: 232-245.

28. Ekunwe PA and HI Ajayi. Economics of plantain production in Edo State Nigeria. Res J Agric Biol Sci. 2010; 6:902-905. 